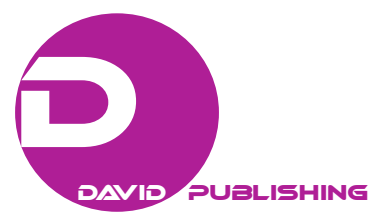

\title{
Bankers' Views Towards Islamic Banking and Islamic Marketing: The Case of Libyan Main Wahda Bank in Benghazi City
}

\author{
Sabri Elkrghli \\ University of Benghazi, Benghazi, Libya \\ Abtesam Yahya \\ Wahda Bank, Wahda, Libya
}

\begin{abstract}
The research topic of this paper is about the transformation process of Libyan Main Wahda Bank to Islamic Banking, and how Islamic Marketing has been practiced in this bank. The study aims to investigate bankers' views towards Islamic Banking and Islamic Marketing practices in Benghazi City. Few interviews with bankers were conducted to design the research instrument, which validated and circulated to bankers responsible for Islamic Banking affairs at Wahda Bank. Data were collected and analysed using Statistical Package for Social Sciences (SPSS). Tests of normality mean scores, T-test, Anova, Correlations and Reliability Analysis were all used in this research paper. The key finding is that there is a consensus among participants that the bank faces numerous challenges including: cultural obstacles, insufficient regulations, increasing environmental challenges, weaknesses of higher authorities responsible for banking affairs, weakness of technology, and poor administrative performances. The study exhibited low level of customer satisfaction on Islamic banking products marketed. The study urges the need to develop a governmental Islamic banking strategy to focus on spreading Islamic Banking and Islamic Marketing culture. Learning from leading Islamic countries' experiences would be a critical future step to develop Libyan banks' practices. It also advises reconsidering the current banking legislations, and explaining their implications properly. Islamic Marketing and customer satisfaction measurement should be given a priority in bank's future strategies. Finally, the paper concludes with research limitations, implications and suggests future research.
\end{abstract}

Key words: Islamic Banking, Islamic Marketing, Wahda Bank, Libya

\section{Introduction}

Investigating Banking personnel views towards the transition process to Islamic Banking Services is considered to be one of the most important modern subjects that need to be further researched especially in the Muslim countries.

Sabri Elkrghli, assistant professor, Department of Marketing, Faculty of Economics, University of Benghazi, Benghazi, Libya. Abtesam Yahya, researcher acts in Islamic Products Department, Main Wahda Bank, Wahda, Libya.

Correspondence concerning this article should be addressed to Sabri Elkrghli, Department of Marketing, Office No. 2, Faculty of Economics, University of Benghazi, Benghazi, Libya. 
Islamic Finance and Islamic Marketing are essential parts of the global economic system and cannot be isolated. They are viewed by Islamic scholars to be a perfect holy system for humans (Dawabah, 2013). Recently, it has been noticed that a new generation of customer services has emerged following the instruction of Islamic Sharia. Great numbers of conferences - throughout the world - have been organised to discuss Islamic Marketing emerged issues.

On the Arabic and Islamic level, Islamic Banking has achieved large success by the expansion of its geographical area, the Islamic banking customer service has spread to more than 60 countries including Malaysia, Indonesia, Pakistan, the United Kingdom, Saudi Arabia, the Arab Emirates, Qatar, Jordan, Egypt, Turkey and others (Al Sheikh \& Shaker, 2009).

In the Libyan case, especially after issuing the Decree Number (1) for the year 2013 that prohibits all usury transactions, all financial and banking institutes took steps to transition to Islamic Banking and Islamic Marketing using Murabaha method to provide customers with their needs especially automobiles and construction equipment.

And since the modern marketing concept embraces customers' needs and wants as a philosophy, it has become mandatory for bankers to think of using the marketing approach to segment the market based on customers' needs and wants. Bankers need to put more efforts to please their customers in a way that achieves mutual satisfactory results.

Nowadays, Islamic banks are competing globally with other traditional commercial banks in the world. Hence, it has become vital for Islamic banks to market themselves in a way that distinguishes them from traditional banks to serve Islamic segments in the market that have needs and wants which cannot be fulfilled except by Islamic Marketing products.

Hence, the current research sheds more lights on the significant role of Islamic Finance and Islamic Marketing for theory and practice. For that end, this paper has been structured as follows: introduction, literature review, research problem, objectives, hypotheses, methodology, fieldwork \& results.

\section{Literature Review}

Recently, Islamic Banking and Islamic Marketing are considered to be among the most prominent subjects that have received growing attention. Islamic Banking refers to the extent to which financial transactions are compatible with Islamic Sharia (Al Ajlouni, 2010).

The interest rates that commercial banks pay for deposits or take for loans are considered usury, a deadly sin in Islam, and the first Islamic bank was established in Dubai in 1970. After that, a number of Islamic banks that exceeded 100 banks worldwide were established. The most famous ones are Faisal Islamic Bank and Dubai Islamic Bank (Auraikat, 2012).

As to Islamic marketing, it is newly-established discipline and there are several explanations and endeavors to define it, especially after the weakness of traditional marketing definitions to fulfill Muslim consumers' needs and wants that are based on Faith and Fear of Allah (Adnan, 2013).

Jafari (2010) for example, defines Islamic Marketing as the science that investigates marketing from the perspective and principles of Islamic societies. According to this view, Islamic marketing can be understood as marketing based on religion (Alserhan, 2016), where all marketing activities will be impacted by Islamic Sharia. It might also mean those marketing practices are undertaken by companies and Muslims towards Muslim consumers. 
Others perceived Islamic Marketing as a redefinition to the traditional marketing concept to mean the adjusting of contemporary marketing concepts in the world to work under the umbrella of the Holy Quran and Sunna, and universally recognized Islamic ethics.

For this, Islamic Marketing has been defined from this point of view to be:

A process or strategy of Hikma (wisdom) in meeting the needs of customers through marketing of Halal products - commodities or services - with the existence of mutual satisfaction between buyer and seller agreement to achieve material and moral prosperity in this life and the hereafter. (Mahabub \& Shariful, 2011, p. 4)

This comprehensive definition reflects the following key elements: strategy or Hikma, need, Halal or Tayyibat (good things), mutual agreement, prosperity or success (Mahabub \& Shariful, 2011, p. 4).

The traditional and contemporary marketing mix — especially in the field of service marketing —or what is called 7Ps does not completely agree with Islamic marketing requirements, and some of the features of this agreement are achieved through social and environmental marketing concepts (Sadeq, AbulHasan, \& Ahmad, 2004).

This deficiency in the agreement has led some authors concerned with Islamic marketing affairs to suggest adjusting the marketing mix to contain other important dimensions such as Muslim's needs and wants (Bin Abdallah \& Jamil, 2013). This implies the need to look at what is called the 5Cs in the field of Islamic marketing: Conformity, Character, Commitment, Conscience, and Customer Centrism.

The close scrutinize to the definition above might bring some ambiguity that could be caused by the use of the term Islamic Marketing. For example, there are some people who consider using the Islamic Marketing term could create a sort of distinction or isolation in understanding the marketing concept. The term might give the idea that it is derived from the Islamic ideology only, and thus it uses certain resources, skills, and tools that appeal to a certain segment and not others. Hence, it deals with Muslim segments and does not interact with non-Muslim consumers. In addition, this definition of Islamic Marketing assumes that a Muslim segment is already in the market and could easily be reached and targeted, and has its behavior predicted by the marketers.

These assumptions about Islamic Marketing might make it a source of danger in understanding Islamic commerce and marketing, and the marketing practices in the world, unless it is presented in a context that accommodates and captures other religions and cultures, with the preserving of Islamic Sharia requirements that Islam brought (Ozlem, 2011).

In the same context, Abu Dalbooh (2014) investigated the impact of market orientation on Islamic Jordanian Banks' performances. He found that public and private banks that transitioned to Islamic Banking face great competition and challenges. These challenges require creating change in the dominant marketing philosophies that govern the bank culture. It is also worth taking into account the competitive capabilities of other banks, which require the need to be unified in large bank entities able to defend themselves in the banking market.

On the other hand, Al Aboud (2010) conducted a study about measuring customer satisfaction on Islamic Banking services quality in the state of Syria. The study showed that there is a noticeable weakness in applying Islamic commands in Syrian Islamic Banks. As a consequence, a negative evaluation was provided by customers to the quality of Islamic products marketed by banks including: Tangibility, Reliability, Responsiveness, Assurance, and Sympathy. These dimensions of customers' satisfaction are considered to be crucial for Islamic marketing services by numbers of scholars (Al Wadi, 2012). 
In their study about customer satisfaction on Islamic Banking Services, Abdul Hasan and Salma (2003) reached to important results about Islamic Banking Services dimensions. The study showed that the Islamic ethical values bring together the most important principles of Muslim customers such as: maximizing values, equality, fairness, and society prosperity. It also found that adherence to Islamic ethics clearly contributes to evaluating the behaviors of both the receiver and the provider of Islamic Banking Services. It can also be added that the need for market orientation - that is based on understanding the customer — is steadily increasing these days, especially with the growing complexity of the marketing environment in the Islamic banking market, and the presence of intense competition among banks. This, in fact, requires that these banks should correct the cognitive comprehension of the customer about Islamic Marketing services in the banks to appear as true Islamic banks.

In another study in Jordan, Al Attiat (2007) confirmed the effectiveness of the transition process to Islamic Banking and Islamic Marketing. The study revealed an important result showing that the success of transitioning process to Islamic Banking in Jordan coupled with the existence of Islamic financial markets, capable human cadre, and correct understanding of Sharia rulings.

In another study about the success of Islamic Banks in providing acceptable Islamic Financial Services to customers in Palestine, Al-Khaldy's (2006) study showed that there is a general satisfaction on Islamic Banking services quality offered in the market, although a gap still exists between the expected Islamic banking service and the received one. There was also a clear variation among customers in evaluating the quality of services due to demographical differences.

In his study about the transition to Islamic Marketing in Saudi Banks, Mustafa's (2006) study indicated the success of the transition process in Saudi Arabia on one hand. In addition, the study confirmed the important fact that the success of this experience is closely related to the common knowledge of Islamic ideology in this country among the bank workers and the customers. Furthermore, the study disclosed that taking into account customers' needs and wants was another factor that helped in the success of Islamic banking experiences in this Islamic Kingdom.

In Sudan, Al-Hazeem's (2004) study on the transition of Sudan Central Bank to Islamic Banking showed that there are some basic conditions needed for the success of transition experience. Correcting the political, legal, and economic environment, and learning from successful and unsuccessful countries' experiences, are considered the starting point in the success of Islamic Marketing Services.

In Sharjah, Hassan (2001) investigated the success factors of traditional banks transition that converted to Islamic Banking, and he found several critical factors in this respect. Putting a clear transition plan, providing expected and legitimate answers to potential transition problems, establishing a specialized Fatwa Department that supervises the transition process, settling shareholders' rights resulted from accumulated usury interests of past years, settling previous loans and deposits, training banks' personnel, and adjusting accounting and financial systems in accordance with the requirements of Islamic Sharia are the key critical factors for the transformation process to Islamic Banking and Islamic Marketing.

In Saudi Arabia, Abu Ghodda (2002) inspected traditional banks transitioning to Islamic banking. The study indicated that the gradual transitioning is the key to success to Islamic Marketing in banks. In addition, the study found that following Sharia's legislations is an effective factor in the transition process success to Islamic banking services. This, in fact, ensures agreement between ideology and behavior, which is considered a form of worship in Muslim countries. 
In Saudi Arabia as well, Al Baali's (2000) study investigated the transition of traditional banks to Islamic banking services. The study disclosed that the success of transition to Islamic Marketing in banks requires restructuring the traditional organizational structures. This, in fact, dictates reviewing administrative, financial, and legal infrastructure to be adjusted with Islamic Sharia (Ameen, 2011).

In the Gulf countries, Yusri's study (1999) examined the transformation process of traditional banks to Islamic Banking. The study exhibited that there are several impediments that hinder the complete transition to Islamic Banking. The dominance of traditional banks policies and regulations in most Arab states, the lack of Islamic ideology knowledge, the deficiency of laws and legislations derived from Sharia, the absence of banks' Islamic vision, and the dominance of Western banking philosophy are the key obstructions observed.

As a final evaluation of the above studies, and despite the fact that those studies have been carried out in different countries over the world, it is clear that there is a great consensus among scholars on the most important factors of transitioning to Islamic Banking and Islamic Marketing.

Taking into account Islamic Sharia's rules, reviewing previous administrative and financial practices, settling financial accumulations and offences in old transactions, qualifying traditional bank workers to help them understand the spirit of Islamic Sharia at work, spreading the Islamic banking culture among customers of Islamic Banking products were seen to be critical factors for the success of Islamic Marketing in the banking sector.

\section{Research Problem}

It is widely known that one of the main roles of banks is supporting and flourishing the global economy by acting as an intermediary between money borrowers and lenders. The first one is looking for money, and the second is seeking best investments and returns. By doing this, banks can raise the standard of life for citizens and customers in the society.

These great ambitions are exactly what the philosophy of Islamic Banking Services seeks. Islamic banks services try to contribute to building true economies using their various types such as Murabaha, Partnership, Leasing, Muzaraa, etc.

The importance of Islamic Marketing of banking services is clearly noted in several Islamic countries. These services need to support Islamic economies in a way that is compatible with Islamic Rulings, and prohibiting any type of economic transactions that contradicts with Islamic morals.

As a result of Islamic marketing importance for clients and society, and despite the start of transition to Islamic Banking way, it is noted that the Islamic marketing products provided by banks are still below the required levels that satisfy Muslim customers.

From few interviews conducted with chief officers in the main Wahda Bank in Benghazi City ${ }^{1}$, it was clearly noted that the Libyan banks are still at the early stages and have not been able to make a full transition to Islamic Banking in its true sense yet.

This, in fact, refers to the existence of a number of obstacles that need to be investigated. As a consequence, Libyan banks were unable to achieve their Islamic marketing ambitions by marketing products to

\footnotetext{
${ }^{1}$ Five interviews were conducted with Islamic Marketing manager, officers, and employees in Wahda Bank to investigate and collect as much information as possible before conducting the main fieldwork study.
} 
their customers satisfactorily and profitably. For that reason, the current study tries to investigate this issue further with the application in the largest bank in Benghazi City.

\section{Research Objectives}

As in all scientific studies, there is a set of goals that need to be achieved in this research paper as shown below:

1. To identify Libyan bankers' opinions towards Islamic banking transformation process and marketing its products in Libyan Wahda Bank.

2. To underline the main obstacles that hinder the speed of transformation process to Islamic Banking.

3. To identify the extent to which Wahda Bank is capable of marketing Islamic products that satisfy customers' needs in Benghazi City.

4. To test the extent to which demographical and organisational variables might affect respondents' responses.

5. To put forward some theoretical and practical implications that contribute to speeding up the transition process to Islamic Banking and Marketing its products in a way that satisfies customers and achieves rewarding revenues to Wahda bank.

\section{Research Hypotheses}

To achieve the research objectives, it has been necessary to refer back to the extant literature and interviews' results to be able to put forward the following hypotheses:

H01: The main Wahda Bank in Benghazi could not completely transition to Islamic Banking.

H11: The main Wahda Bank in Benghazi was able to completely transition to Islamic Banking.

H02: There are no obstacles that hinder Wahda Bank from transitioning to Islamic Banking and Marketing its products.

H12: There are obstacles that hinder Wahda Bank from transitioning to Islamic Banking and Marketing its products.

H03: Wahda Bank does not market Islamic products that make high level of customer satisfaction.

H13: Wahda Bank markets Islamic products that make high level of customer satisfaction.

H04: Wahda Bank does not market Islamic products that attract high level of customer demand.

H14: Wahda Bank markets Islamic products that attract high level of customer demand.

H05: There are no significantly statistical differences among participants' views that might be attributed to demographical and organisational variables.

H15: There are significantly statistical differences among participants' views that might be attributed to demographical and organisational variables.

\section{Research Methodology}

In order to achieve the research objectives, the methodology that was adopted concentrated on reviewing and extrapolating previously published literature on Islamic Banking and Islamic Marketing literature. This step has been taken to find valid and reliable constructs to be used in the current study. In addition, a number of semi-structured interviews were also carried out with chief officers of Islamic Marketing in the main Wahda 
Bank in Benghazi City. Furthermore, a number of Libyan official statistics - published by Audit Department in the year 2016 - were used as references as well.

\section{Research Variables}

This current study encompassed a set of demographical variables including: gender, qualifications, specialty, work experience, and job position. It also included other key variables such as customer satisfaction on Islamic products, and obstacles of transitioning to Islamic banking.

The later consisted of the following: obstacles caused by top state authorities, obstacles caused by bank management, obstacles caused by Islamic marketing department, obstacles caused by Sharia jurisprudence, obstacles caused by bank personnel, obstacles caused by customers, obstacles caused by surrounding external environment, and finally obstacles caused by weak technology adopted at the bank. All these variables have been studied due to their close connection with the research problem.

\section{Sampling}

The study targeted Islamic Marketing Department at main Wahda Bank in Benghazi City, with a special focus on all organizational units involved in launching and marketing Islamic products in the bank. To that end, individuals responsible for Islamic banking and marketing have been targeted. Hence, a number of 50 questionnaires were distributed. Out of this number, only 30 questionnaires were returned with 26 deemed valid for the analysis stage. This number of returned valid questionnaires represents a response rate of $52 \%$, and this percentage — despite being low_-gives a primary indicator about Islamic Marketing practices at banks in the Libyan banking sector.

\section{Measurement}

To achieve the goals of this study and testing its hypotheses, and after surveying the extant literature on Islamic Banking and Islamic Marketing, a pilot-study was conducted with a sample of Islamic Department officials at main Wahda bank in Benghazi City. Five interviews were conducted for the purpose of reviewing and refining the questionnaires that were used as a main tool in collecting the research data. The questionnaire was designed to fit with the nature of the study using five-point Likert scale.

In order to validate the research instrument, a number of academicians and experts at University of Benghazi were requested to refine and validate the questionnaire. Some chief officers of Islamic Marketing Department at main Wahda Bank were also requested to comment the research instrument. These steps were taken to guarantee high degree of validity and reliability in the research instrument as recommended (Churchill, 1979).

As it is known, validity means the degree to which the scale can measure what is to be measured. The reliability refers to the quality of internal consistency of the questionnaire items, its stability, its ability to represent the concept to be measured, and the possibility of replicating the study.

The reliability analysis only validated 60 items out of 71 included in the questionnaire, where Cronbach's Alpha values range between 0.77-0.97. These values are considered suitable to the study and exceeded the recommended cut-off point $\alpha=0.70$ for the scale to be reliable.

\section{Fieldwork Study \& Results}

After collecting the questionnaires, the data were entered into SPSS for scanning and purification before running the analysis. The data distribution was much closer to Parametric Distribution, where Tests of 
Normality showed an increase in the statistical value of Kolmogorov-Smirnov ( $>0.05)$. The following next sections provide the most important results.

\section{Demographical Information}

This part of the analysis shows the descriptive results obtained from the field work study.

\section{Qualifications}

It is well known that qualification is one of the most important factors that affect individuals' attitudes and their ability to comprehend and evaluate events they come across at work. For that end, personnel qualifications' information at main Wahda Bank in Benghazi was collected and depicted in Table 1 below.

Table 1

\section{Participants' Qualifications}

\begin{tabular}{lll}
\hline Education level & Frequency & Percentage \\
\hline PhD \& MSc & 6 & 23 \\
BSc/Dip & 17 & 65 \\
High school & 3 & 12 \\
Total & 26 & 100 \\
\hline
\end{tabular}

From Table 1 above, it can be seen that there is an increase in participants' qualifications levels. For instance, $23 \%$ of them have $\mathrm{PhD}$ and $\mathrm{MSc}$, and $65 \%$ have $\mathrm{BSc}$ and Diploma, whereas the remaining participants (12\%) have lower degrees. The accumulative percentage of high education participants (88\%) might be seen as an encouraging factor to increase our confidence in the collected data, so as to make us expect good practices of Islamic Marketing services in main Wahda bank in Benghazi.

\section{Work Experience}

This variable is considered as an important factor that affects participants' attitudes and perceptions towards different events they encounter in their career. Work experience contributes to the way an individual perceives and evaluates events and situations faced during his career. The following table shows the work experiences of participants.

Table 2

Work Experience

\begin{tabular}{lll}
\hline Experience & Frequency & Percentage \\
\hline Less than 5 years & 2 & 8 \\
From 5-less than 10 & 5 & 19 \\
10 and more & 19 & 73 \\
Total & 26 & 100 \\
\hline
\end{tabular}

From Table 2 above, it can be seen that participants' work experiences reached high level of $92 \%$ in banking services. This high level of work experience might have statistical implications when identifying the extent to which this factor causes differences among participants' responses.

\section{Participants' Specialty}

This is considered an important variable that could have an effective impact on individuals' tendencies and their evaluation of events and situations they face at work. The specialty element plays a pivotal role in 
understanding work details and evaluating them properly to make the right decisions. More details on this factor can be found in Table 3 below.

Table 3

Participants’ Specialty

\begin{tabular}{lll}
\hline Specialty & Frequency & Percentage \\
\hline Business administration & 7 & 27 \\
Accounting & 8 & 31 \\
Economics & 5 & 19 \\
Others & 6 & 23 \\
Total & 26 & 100 \\
\hline
\end{tabular}

From Table 3 above, it can be noticed that $77 \%$ of participants are specialized in Business administration, Accounting, and Economics. This relatively high percentage can have a statistical effect when studying the expected effects of specialty on causing differences among participants' responses.

\section{Participants' Organisational Positions}

The nature and level of jobs that individuals hold in their institutions have a very important role that might affect their attitudes and evaluations to events and other issues they face at work. The following table shows more details on this part.

Table 4

Participants’ Organisational Positions

\begin{tabular}{lll}
\hline Organisational position & Frequency & Percentage \\
\hline Managers & 6 & 23 \\
Officers & 11 & 42 \\
Other positions & 9 & 35 \\
Total & 26 & 100 \\
\hline
\end{tabular}

From Table 4 above, it can be noticed that $65 \%$ of participants are in chief leading positions in the main Wahda Bank in Benghazi City, and thus their opinions are considered crucial and might have statistical significance, especially when investigating the expected effects of organisational position level on participants' responses.

\section{Gender of Participants}

As proved in several researches, gender is another element that might have an effect on shaping individuals' perceptions and evaluation to events and situations they encounter in daily activities at work. This disparity in human physiology could have its significance when conducting the statistical tests. More details on this element can be found below.

Table 5

Gender

\begin{tabular}{lll}
\hline Gender & Frequency & Percentage \\
\hline Male & 18 & 69 \\
Female & 8 & 31 \\
Total & 26 & 100 \\
\hline
\end{tabular}


According to the data presented above, most of the participants $(69 \%)$ are Males, while the remaining (31\%) are Females. This divergence might have its statistical effect when testing the research hypotheses.

\section{Main Research Data}

To assess personnel attitudes towards the transition process towards Islamic Banking and Islamic Marketing, a questionnaire was designed for that purpose. Responses were collected and analysed as demonstrated in the sections below.

\section{Transition to Islamic Banking Services}

After issuing the Decree number (1) for the year 2013, which organizes Islamic Marketing services in Libya, all Libyan banks started the transitioning process to Islamic Banking services. This law was issued to prohibit all usury transactions, and to force banks to revise their activities and adjust them to fit with Islamic Sharia. In other words, banks should follow standard number (6) of Sharia standards, which organizes the transition from traditional banking to the Islamic one, with the aim of delivering Islamic products that satisfy Muslim consumers.

To find out the extent to which main Wahda bank has transformed to Islamic Banking services, a clear question was directed to Islamic Marketing personnel at main Wahda Bank in the City of Benghazi, and their responses collected and are presented in Table 6 below.

Table 6

Transitioning to Islamic Banking Services

\begin{tabular}{|c|c|c|c|c|c|c|c|c|}
\hline \multirow{3}{*}{ Data } & \multicolumn{6}{|c|}{ Transition degree } & \multirow{3}{*}{$T$-test } & \multirow{3}{*}{$p$-value } \\
\hline & \multicolumn{2}{|c|}{ Complete transition } & \multicolumn{2}{|c|}{ Partial transition } & \multicolumn{2}{|c|}{ Total } & & \\
\hline & No. & Per. & No. & Per. & No. & Per. & & \\
\hline $\begin{array}{l}\text { Has Wahda Bank transitioned } \\
\text { to Islamic Banking Services? }\end{array}$ & - & - & 26 & 100 & 26 & 100 & 0.72 & 0.48 \\
\hline
\end{tabular}

It is clear from Table 6 above that there is a consensus among participants on the failure of Wahda Bank to completely transition to Islamic Banking. This consensus is confirmed through the statistical value $(T$-test $=$ 0.72 ), and the statistical significance ( $p$-value $>0.05$ ). This leads us to accept the Null Hypothesis that states "main Wahda Bank in Benghazi City could not transition completely to Islamic Banking".

This result indicates that obstacles hinder Wahda Bank to achieve the complete transition to Islamic Banking services according to Sharia rulings.

\section{Obstacles of Islamic Banking Transition}

Transition to Islamic Banking and Islamic Marketing is considered one of the most important features of modern banks and financial institutes in the world. Numerous developed, Islamic and developing countries have started to introduce Islamic Finance and Islamic Marketing subjects in their educational programs.

And despite issuing the Libyan Islamic Banking Transition Decree in the year 2013, the transition process is still suffering from obstacles that hinder the speeding of the transition process to Islamic Banking and Islamic Marketing as hoped.

The current study exhibited several internal and external impediments that hinder the speedy transition to Islamic Marketing services at Wahda Bank. More details can be found in Table 7 below.

Table 7 below shows a number of related obstacles that hinder the speeding up of transition process to the Islamic banking services in main Wahda Bank, and these obstacles are closely correlated with each other. The 
correlation coefficients ranged between $0.43-0.84$, and those coefficients reflect positive correlation among all these obstacles.

In addition, the overall mean of those obstacles was 3.88 on a five-point Likert scale. This mean score exceeds the hypothetical mean of 3 , which clearly displays the evident role of those obstacles in hindering Wahda bank from transitioning to Islamic Marketing as required in a way satisfying Muslim customers in Libya.

Table 7

Obstacles to Islamic Banking Transition

\begin{tabular}{|c|c|c|c|c|c|c|}
\hline Obstacles & $\mathrm{N}$ & Mean & SD & Correlation & $T$-test & $p$-value \\
\hline External environment & 26 & 4.02 & 0.830 & $* 0.46$ & \multirow{10}{*}{9.27} & \multirow{10}{*}{0.000} \\
\hline Workforce & 26 & 4.01 & 0.622 & *0.72 & & \\
\hline Customers & 26 & 3.95 & 0.576 & $* 0.59$ & & \\
\hline Technology & 26 & 3.91 & 0.765 & $* 0.84$ & & \\
\hline Department of Islamic products & 26 & 3.85 & 0.683 & $* 0.78$ & & \\
\hline Top management & 26 & 3.80 & 0.667 & $* 0.79$ & & \\
\hline Ministry of finance \& central bank & 26 & 3.69 & 0.649 & *0.84 & & \\
\hline Sharia supervisory board & 26 & 3.57 & 0.610 & $* 0.43$ & & \\
\hline Regulations & 26 & 3.48 & 0.630 & $* 0.77$ & & \\
\hline Overall mean of obstacles & 26 & 3.85 & 0.480 & - & & \\
\hline Gender's effect & - & - & - & - & 0.56 & - \\
\hline Qualification's effect & - & - & - & - & - & 0.06 \\
\hline Specialty's effect & - & - & - & - & - & 0.08 \\
\hline Work experience's effect & - & - & - & - & - & 0.56 \\
\hline Organisational position's effect & - & - & - & - & - & 0.97 \\
\hline
\end{tabular}

Note. ${ }^{*}$ Correlation coefficients are significant at $\alpha=0.05$.

This result is also supported by $T$-test value $=9.27$, and the value of statistical significance $p$-value $<0.05$. This, in turn, leads us to reject the second Null Hypothesis that states: "There are no obstacles that hinder Wahda Bank from transitioning to Islamic Banking and Marketing its products". This result reflects the existence of genuine deterrents that hinder Wahda Bank from completely transitioning to working according to Islamic Sharia.

For further elaboration on this result, the mean scores of Islamic Banking impediments can be ordered sequentially as follows: obstacles related to external environment (4.02), obstacles related to workforces weak performance (4.01), obstacles related to customers weak comprehension of Islamic Banking rules (3.95), obstacles related to lack of technology applied in Islamic Banking (3.91), obstacles related to the weak role of top management of the bank (3.80), obstacles related to the weak role of Ministry of Finance and Central Bank (3.69), obstacles related to the weak role of Sharia Supervisory Board in the bank (3.57), and finally obstacles related to the weaknesses of laws and regulations that organize Islamic Banking affairs (3.48).

To test the extent to which demographical factors have an impact on differentiating between participants' responses about Islamic Banking and Islamic Marketing obstacles, $T$-test and a one-way Anova analysis were carried out. The analysis showed that no differences have been noted that can be attributed to qualifications, specialty, experience, and organisational positions as $T$-test value and $p$-value $>0.05$. 
Thus the third Null Hypothesis that states: "There are no significant statistical differences among participants' responses can be attributed to demographical and organisational factors" will be accepted. This, actually, confirms participants' consensus on obstacles that hinder the acceleration process to Islamic Banking services.

\section{Customer Satisfaction on Islamic Banking Products}

As it is widely known in marketing literature customer satisfaction and market orientation strategies are considered to be the most important approaches modern banks can use to achieve high performance. These strategies are crucial in attracting more market segments and penetrating extra new markets. This, as a consequence, will enlarge businesses' market shares, consolidate their competitive positions, and increase their profit levels.

To measure customer satisfaction on Islamic Banking and Islamic Marketing products offered by main Wahda Bank in Benghazi City, a number of questions were directed to Islamic Marketing Department Officers about their views on these issues. The responses were collected and presented in Table 8 below.

Table 8

Customer Satisfaction on Islamic Banking Products

\begin{tabular}{|c|c|c|c|c|c|c|}
\hline$\overline{\text { Data }}$ & $\mathrm{N}$ & Mean & SD & $T$-test & $p$-value & Hypothesis \\
\hline To what extent customers are satisfied with your Islamic Products? & 26 & 2.69 & 0.88 & 1.77 & 0.08 & Acceptance \\
\hline To what extent customers buy your Islamic Products? & 26 & 3.65 & 0.83 & 3.27 & 0.003 & Rejection \\
\hline Correlation & - & - & $0.41 *$ & - & - & \\
\hline
\end{tabular}

Note. *Correlation coefficients are significant at $\alpha=0.05$.

From Table 8 above, it is clear that there is a decrease in customer satisfaction regarding Islamic Banking products (e.g. automobiles, furniture, electric, and household appliances) as the mean score reached 2.69 on a five-point Likert scale. This is also confirmed by $T$-test value, which was not statistically significant as $p$-value > 0.05. This result leads us to accept the hypothesis that states: "Islamic Products Department at main Wahda Bank does not market Islamic products that achieve high level of customer satisfaction".

From the same table as well, it can be noted that there is a relative increase in customer demand of Islamic Banking products as the mean score of customer demand reached 3.65. In addition, $T$-test value was statistically significant as $p$-value $<0.05$.

This value leads us to reject the Null Hypothesis that states: "Islamic Products' Department at main Wahda Bank does not market Islamic products that attract high level of customer demand".

A quicker look at the nearly contradicting two results above-decrease of customer satisfaction against increase of customer demand - shows that this increase does not reflect a genuine desire came from customers to acquire those products for their own features, as much as it reflects a type of pressure to acquire them for numerous different reasons. Those reasons differ from the marketing philosophy and consumption buying behaviour motivations, which aim at satisfying customer as shown in Table 9 below.

From Table 9 below, it can be perceived that the relative increase in customer demand on Islamic Banking products is caused by motives unrelated to Islamic products' main characteristics. Liquidity came first as a genuine cause for preferring to acquire Wahda's Bank products with a mean score of 4.50. Lack of superior substitutes came second with mean score of 3.62, and limited consumer's incomes came in the third sequence with mean score of 3.42 . 
Table 9

Reasons for Customer Demand on Islamic Products

\begin{tabular}{llll}
\hline Reasons & $\mathrm{N}$ & Mean & SD \\
\hline Reselling Islamic products for attaining liquidity & 26 & 4.50 & 0.762 \\
Lack of better or superior substitutes & 26 & 3.62 & 0.134 \\
Limited consumer incomes force them to accept current Islamic products & 26 & 3.42 & 0.845 \\
The desire to acquire existing Islamic products for their respectable features & 26 & 2.96 & 0.871 \\
Uniqueness of Wahda's Bank Islamic products & 26 & 2.85 & 0.664 \\
\hline
\end{tabular}

On the other hand, the most rational reasons for acquiring Islamic products-product characteristics and superiority - did not acquire high degree of customers' preferences as their means scores were observed to be low (2.96 and 2.85) consecutively.

Finally, the closer look at the correlation coefficient of customer satisfaction and product orders will provide more meanings. As can be seen from the figures, a moderate positive correlation (0.41) exists between customer satisfaction on current Islamic Banking products, and product orders. This result might come close to being natural and logical; the level of demand or preferences increases on those Islamic Banking products as satisfaction level increases.

\section{Discussion \& Conclusions}

The present study represents great scientific efforts that required material, efforts, and time as resources to achieve and bring to light the study in its current state. These efforts will not have valuable scientific impact unless its conclusion is clearly explained in order to allow others to benefit from its findings. The following sections shed more lights on this part.

\section{Summary of Results}

After collecting and analyzing the data, a number of key results and conclusions have been reached as explained below:

1. There is an increase in the level of participants' qualifications and their work experience. In addition, a high degree of harmony between qualification and specialty is evidently perceived. This is expected to be very useful for Islamic Banking and Islamic Marketing applications.

2. There is a complete consensus among males and females on the inability of the main Wahda Bank in Benghazi City to completely transition to Islamic Marketing services. These stumbling steps are due to the existence of numerous obstacles that hinder the rapid and full conversion to Islamic Banking and Islamic Marketing as noted above.

3. The study confirmed nine real obstacles that hinder the acceleration of a proper transition to Islamic Banking at main Wahda Bank in Benghazi City. External environment factors, weakness of workforce's skills in Islamic Banking and Islamic Marketing, weakness of customer knowledge and their misunderstandings of Islamic Banking affairs, lack of technological applications in Islamic Banking at Wahda bank, weakness of Islamic Banking Department at main Wahda bank, weakness of top management in managing Islamic Banking Affairs, the weak roles of Ministry of Finance and Libyan Central Bank in dealing with Islamic Banking and Islamic Marketing matters, the weak role of Sharia Supervisory Board at main Wahda bank, and finally the weakness of regulations that oversee Islamic banking affairs are key obstacles to transformation process to Islamic Banking and Islamic Marketing. 
4. The study did not spot any differences among participants' responses in relation to transition obstacles that could be attributed to qualifications, specialty, work experience, and organisational positions.

5. The results show a weakness in Islamic Marketing tools at main Wahda Bank, indicating a decrease in customer satisfaction on Islamic Banking products offered through Murabaha approach (automobiles, furniture, electrical, and household appliances).

6. Despite the low level of customer satisfaction on those marketed banking products, the study showed an increase in customer demand and preferences to Islamic Banking products. The relatively high demand of Islamic Banking products does not reflect a genuine desire of customers to acquire the products per se, as much as it reflects their need to the products for numerous reasons that differ from marketing philosophies and product motives.

The need for liquidity came first as a reason for preferring to buy Islamic Banking products in order to resell them later on. The absence of better substitutes and the limited customers' incomes came next sequentially, whereas the most important reasons for the demand on Islamic Banking products - characteristics of products and their uniqueness - did not attain a high level of customer preferences. This contradiction sheds the light on the fact that Islamic marketing products were not requested for their own benefits as much as their own financial values during the financial crisis that the Libyan state has been facing over the last three years.

7. The study showed medium positive correlation between customer satisfaction on Islamic products, and the level of customer demand and eagerness to purchase. This means that the level of customer demand increases with the increase in customer satisfaction.

Although this is generally considered as alogical result, it has been contradicted in the current study, as there is an increase in customer demand of Islamic banking products, despite the decrease in the level of satisfaction. This, indeed, highlights the emergent effect of Libyan financial crisis on Libyan business environment.

\section{Discussion}

The most prominent results reached in this study are that it is not possible to understand the scientific value of the research unless it is compared with previous studies conducted in the field of Islamic Banking and Islamic Marketing.

For instance, the current study exhibited clear weakness in considering customer satisfaction and offering satisfactory Islamic Banking products that agree completely with Islamic Sharia requirements, and meet customers' demands and preferences. This result is compatible with previous findings reached in other similar studies (Al Aboud, 2010) in Syria, and (Al Khaldy, 2006) in Kuwait.

On one hand, this result contradicts with another study (Mustafa, 2006) in Saudi Arabia. This research reached the result that the success of transitioning process to Islamic Banking in Saudi Arabia was closely connected with achieving high levels of customer satisfaction on Islamic Banking products and this, in turn, was associated with effective Islamic Banking and Marketing strategies.

This current study also agreed with another study conducted in Jordan (Al Attiat, 2007). The study revealed that the low level of success in transition to Islamic Banking was associated with the absence of Islamic Financial Markets, and the lack of human cadre able to understand the dimensions of Islamic Sharia and rulings.

The results of the current study also agree with the results of other studies conducted in Saudi Arabia (Mustafa, 2006); (Abu Dalboh, 2014). These studies exhibited that the success in the transitional process to 
Islamic Marketing services was closely associated with the correct understandings of Sharia rulings, especially from workforce and customers at the same time.

The findings of the present study also agree with the findings of Al Hazeem's (2004) research in Sudan. The focus of the study was on the extent to which Central Bank of Sudan has transformed to Islamic Banking system. That study presented a number of basic conditions necessary to achieve the success in the transition process. These conditions consist of fixing the political, legal, and economic environment. Gaining lessons from successful and unsuccessful Islamic Marketing transformation experiences at banks is an important step that should be taken.

The results of the current study also agree with the results of Hassan's (2002) research in Sharjah, where his study disclosed that the plan to transition from traditional banking services to Islamic one must have a number of essential factors. Having a clear transitional plan, providing all possible solutions to Sharia problems that might appear in the transition phase, establishing a Fatwa supervisory board to monitor and supervise the transition process, settling shareholders' rights that resulted from accumulated usury interests from past years, settling old loans and deposits, training and qualifying personnel in the bank, adapting accounting and financial traditional theories to fit with Sharia requirements and rulings are essential factors for Islamic Marketing services at banks.

The results of this study also agree with the findings of Al Baali's (2000) study in Saudi Arabia about the transition of traditional banks to Islamic Banking system. The study revealed that the success of transitioning to Islamic Banking necessarily involves reviewing old bank structure to include administrational, financial, and legal systems. Adapting them to Islamic Sharia requirements is a condition to ensure satisfactory success.

It is also noticed that the results of the existing study agree with results of Yusri's (1999) study in Gulf States about the transition of traditional banks to Islamic ones. The study displayed that obstacles of complete transition to proper Islamic Banking were connected with several important factors.

The dominance of traditional banks' regulations in most Arab countries, the absence of the right Islamic cultural ideology, the lack of laws and legislations derived from Islamic Sharia, the absence of Islamic vision in bank activities, and the replacement of Islamic Banking philosophies with Western bank theories are critical impediments to Islamic Banking and Islamic Marketing.

The findings of the study also agree with the findings of other studies that call for the necessity of adopting proper Islamic Banking systems to market their Islamic products in a way that satisfies Muslim customers and makes satisfactory returns to the banks (e.g. Mahabub \& Shariful, 2011; Ozlem, 2011).

Finally, the study agrees with the results of Abu Ghodda's (2002) research about transition of banks to work according to Islamic Banking systems. The study found that gradual or stage-by-stage transition is a key element for the success of Islamic Banking services.

Another key factor is taking into account the correct implementation of Sharia rulings, as it guarantees harmony between human ideology and actual behavior in the market. This, in fact, is a form of worship for customers in Muslim countries.

\section{Implications}

As with all scientific research, implications come to present the final outcomes in the form of recommendations and benefits to those who are expected to benefit from the research conclusions. Hence, a number of key theoretical and empirical implications can be provided as below: 
1. Despite the high level of qualifications and the agreement of academic specialties with job requirements for working in Islamic banks, main Wahda Bank in Benghazi City could not- to this moment - employ the human resources it has to develop proper Islamic Banking infrastructure. This made it difficult for the bank to market its Islamic products in a way that satisfies Muslim customers and achieves satisfactory profits.

2. If the top management of main Wahda Bank wants to apply Islamic Banking philosophies, it needs to formulate strategies for proper Islamic Marketing services at banks. These strategies will help in addressing the challenges that hinder the transition process to Islamic Banking services and guarantee marketing its products successfully.

3. In the context of correcting and adjusting Islamic Banking services at main Wahda Bank, the top management of the bank needs to take a number of corrective steps as follows:

a. Top management of main Wahda Bank needs to make more efforts to contribute in finding solutions to challenges that Islamic Banking Department faces, especially the internal ones that could be resolved to mitigate their negative effects on the bank and its customers.

b. There is a need to address Libyan chief officials in Ministry of Finance and the Central Bank of Libya asking them for putting more efforts to simplify the Islamic transition process by issuing special financial legislations through which problems can be resolved.

c. Top management of main Wahda Bank needs to restructure the Islamic Advisory Board in the bank for further development. This, in turn, will help in correcting and remedying common mistakes committed by Islamic bankers at main Wahda Bank.

d. Top management of main Wahda Bank must take all measures to qualify and develop the workforce knowledge and skills with the focus being placed on Islamic Banking and Islamic Marketing knowledge and practice. This requires internal and external specialized training programmes to be delivered. Learning lessens from successful and unsuccessful Islamic Banking transformation experiences should be given more attention to the bank.

e. Top management of main Wahda Bank needs to implement Islamic Banking educational campaigns that aim at raising customers' awareness. This, consecutively, will develop cstomers' understandings and perceptions, and urge them to adopt Islamic Banking ideas. This, also, will contribute to the success of Islamic Banking and Islamic Marketing programmes offered in the market.

f. Top management of main Wahda Bank must look into the possibility of implementing contemporary technology in Islamic banking services. In addition, the bank needs to benefit from the experiences of pioneering countries in this field such as Jordan, Turkey, Malaysia, and the Gulf States.

g. Urging top management of main Wahda Bank to attain experts' consultations in Islamic Marketing and Islamic Banking. This will assist in spreading the marketing culture at the bank, and offer Islamic products that suit customers' needs and wants rather than accepting products imposed by government or top management in the bank.

h. Scanning the surrounded internal and external environment is another important step that must be taken, and it is critical for the bank to find strategic profitable adaptations that satisfy customers' needs and fulfill Islamic Sharia requirements.

4. There is a need for main Wahda Bank to launch Islamic Banking products that consider customers' needs and wants. This involves thinking seriously in adopting more options that are useful to customers than 
focusing on the sole Islamic approach "Murabaha" currently on offering for a very limited number of products (e.g. automobiles, furniture, electrical, and household appliances).

Islamic Financing, Banking, and Marketing open numerous horizons that can be adopted and applied successfully. In specific, the results of the current study clearly showed that customers buy Islamic products for the purpose of reselling them to obtain liquidity. This, in fact, happened due to the Libyan economic and political crises that the country has been suffering. This matter might urge and encourage new thoughts for more Islamic Banking substitutes to be marketed to Muslim customers.

5. There is a need to review the characteristics of current Islamic Banking products to redesign them in one way or another. This will allow the acceptance of these products for their own characteristics not just for reselling them for gaining liquidity.

6. It is necessary to invest in human resources at the bank, by training, educating, and teaching them the fundamentals of Islamic Banking services. This will encourage and support the bank workforce to be a buttress to the bank that leads to the success of Islamic Banking strategies instead of being obstacles decreasing the profit, and hindering the success of similar Islamic products.

7. The results that have been reached in this paper can be published and circulated to all related official authorities. This should include the Ministry of Finance, Central bank of Libya, Islamic Marketing departments and the bank workforce.

8. From theoretical and philosophical points of view, the current results help Libyan educational institutes such as universities and higher institutes - including scientific libraries, staff, and students - in understanding the theoretical and practical implications of the study that enrich Islamic Banking and Islamic Marketing fields.

9. On an international level, the current results are considered as indicators that highlight Islamic Banking and Islamic Marketing practices in Libya. This, in turn, will help international institutions to benefit from the results and implications for any possible future projects.

\section{Limitations \& Future Research}

The current study has been carried out under several challenges. These constraints could be considered as a motive or incentive to complete this study and reach its conclusions. In specific, three key challenges have been encountered as will be explained below.

1. Because of the particularity of the study, and with reference to the limited knowledge of customers about Islamic Banking transformation affairs, customers were ruled out from being investigated in this research.

2. The inability to target all public Libyan banks that apply Islamic Banking and Marketing systems made it impossible to find participants who represent all Libyan banks.

3. In spite of using self-administered questionnaire to target Islamic Banking and Islamic Marketing workforce in main Wahda Bank, it was not possible to collect all questionnaires circulated. This happened due to different hindrances related to job pressure, and daily burdens that respondents suffer at work. This, in turn, resulted in reducing the small size, and this issue lessens the possibility of generalizing the results reached.

From different point of view, these challenges can actually be perceived as a great opportunity to open new avenues for developing Islamic Banking and Islamic Marketing practices. In specific, the current study suggests the following future studies: 
a. It is recommended to reuse the current research instrument in similar future studies. Instrument replication in other contexts will be an intriguing future research on Islamic Banking and Islamic Marketing. Therefore, postgraduate students might find it a valuable chance to conduct similar research in different settings.

b. It could be very helpful to look at the possibility of carrying out a systematic specialized comparison between the current research results with similar future studies that might reuse the present research instrument. This, in turn, might help in identifying other influential factors that the current study could not discover.

c. Carrying out a deep and comprehensive study on customers' attitudes towards the quality of Islamic Marketing mix offered by Libyan banks will be a fascinating study that complements the current research efforts. It would be more productive study if both sectors: private and public banks have been investigated.

\section{References}

Abdul Hassan, A. C., \& Salma, A. L. (2003). Islamic marketing ethics and its impact on customer satisfaction in the Islamic banking industry. Islamic Economics, 21(1), 1-27.

Abu Dalbooh, M. (2014). The impact of market orientation on the performance of Islamic banks (Case study: Jordanian Islamic banks). International Journal of Engineering Research and Applications, 4(1), January, 31-42.

Abu Ghodda, A. S. (2002). Traditional bank transformation to Islamic bank (1st ed.). Part 3, Tewfik Company, Dalit Al Baraka Group, Jeddah, Saudi Arabia Kingdom, (In Arabic).

Adnan, A. A. (2013). Theoretical framework for Islamic marketing: Do we need a new paradigm? International Journal of Business and Social Science, 4(7), July, 157-165.

Al Aboud, K. (2010). Customer satisfaction on Islamic banking service quality. Journal of Economic and Legal Sciences, 28(2), Damascus University, 551-572, (In Arabic).

Al Baali, A. M. (2000). Requirements of Islamic financial transactions’ strategy in Saudi Arabia. Arabic: Dar Al Rawi Publishing Company.

Al Ajlouni, M. (2010). Islamic banks (2nd ed.). Amman: Dar Al Massira for Publishing, Printing \& Distribution, (In Arabic).

Al Attiat, Y. K. S. (2007). Transforming conventional banks to work according to Islamic sharia: A study to show the viability of application in Jordan (PhD Thesis, pp. 1-238). The Arab Academy for Banking and Financial Sciences, Amman: Jordanian University. Retrieved from: http://www.aabfs.org

Al Hazeem, Y. O. (2004). The transformation of traditional central bank to Islamic bank. Riyadh, Saudi Arabia Kingdom, Arabic: Dar Al Salam Publishing.

Al Khaldy, A. F. F. (2006). Measuring Islamic banking services' quality in Palestine: Customers' points of view (MSc Thesis). Islamic University of Gaza, Postgraduate Studies, Management Department, Arabic.

Alserhan, B. A. (2016). The principles of Islamic marketing (2nd ed.). Rutledge. Retrieved from: https://www.routledge.com/products/search?keywords=alserhan

Al Sheikh, M. H., \& Shaker, T. I. (2009). To what extent Islamic banks apply Islamic banking: Customers' opinions. Zarqa Research and Humanity Studies Journal, 9(1), 101-124. Retrieved from: http://zujournal.zu.edu.jo

Al Wadi, M. N. A. (2012). Marketing of Islamic banking services (1st ed.). Amman: Dar Al Massira forPublishing, Printing \& Distribution, (In Arabic).

Ameen, K. S. H. (2011). Islamic banking operations: Modern accounting methods (2nd ed.), Amman: Dar Waelfor Publishing \& Distribution, (In Arabic).

Auraikat, H. A. S. (2012). Islamic banking management: Contemporary approach (2nd ed.). Amman: Dar Waelfor Publishing \& Distribution, (In Arabic).

Bin Abdallah, J. F. A., \& Jamil, H. H. (2013). Advancing critical factors in Islamic marketing. Research Paper, Sarawak, Malaysia, Faculty of Business Management, Universiti Teknologi MARA, UiTM, Kota Samarahan, 1-8.

Churchill, G. A ., Jr. (1979). A paradigm for developing better measures of marketing constructs. Journal of Marketing Research, 16(February), 64-73.

Dawabah, A. (2013). Islamic banking services. Cairo: Dar Al Salam for Publishing, Distribution \& Translation, (In Arabic). Jafari, A. (2010). Islamic marketing: Insights from a critical perspective. Bingley: Emerald Group Publishing, Limited. 
Mahabub, A., \& Shariful, H. (2011). Marketing: An Islamic perspective. World Journal of Social Sciences, 1(3), July, 71-81.

Mustafa, I. M. M. (2006). Evaluation of traditional banks transformation to Islamic banking: Evidence from some Saudi banks (MSc Thesis). Cairo, Arabic.

Ozlem, S. (2011). Researching Islamic marketing: Past and future perspectives. Journal of Islamic Marketing, 2(3), $246-258$.

Sadeq, M., AbulHasan, \& Ahmad, A. K. (2004).Quality management Islamic perspective. Islamic Foundation Bangladesh, 1-32.

Yusri, A. A. (1999). Traditional banks and the transformation to Islamic Sharia. Research paper introduced to the 16th Baraka Symposium for Islamic Economics, Beirut, Islamic Economy Journal, 229, 1-33. 